\title{
An examination of research trends and constructs concerning frameworks for Sustainable Supply Chain Management (SSCM)-Review Paper
}

DOI : 10.36909/jer.ICETET.14985

\author{
Ashish Patel*, Dr.T.N.Desai,Dr.R.Anjana \\ Department of Mechanical Engineering,Laxmi institute of technology,Sarigam,Gujarat India \\ Department of Mechanical Engineering,Sardar Vallbhbhai National Institute of Technology, Surat, India. \\ Department of Electrical Engineering,Laxmi institute of technology,Sarigam,Gujarat India \\ *Email: ashish.lit@laxmi.edu.in
}

\begin{abstract}
The writing of Sustainable Supply chain Management (SSCM) is overflowed with structures. Be that as it may, to date, there has been no endeavor to uncover the irregularities in the current systems and related research patterns. The motivation behind this paper is to survey SSCM structures and feature irregularities. The examination additionally helps in dissecting exploration patterns and builds of SSCM structures and encourages new applications. It utilizes the Scopus database and concludes a couple of systems in the SSCM are considering a period from 2000-2018, utilizing an organized writing audit approach and space specialists. It uses a battery of deliberate necessities-based inquiries to get patterns and covers building squares/develops. It uncovers irregularities at three unique stages: system arrangement, utilization stage catching existing exploration patterns, and build the structure. It likewise offers subtleties at structure square/develops level. Hence, it provides direction in diminishing irregularities and potential changes in existing systems. It uncovered existing growth and sub-builds and aides about the new forthcoming changes in a business affecting SSCM space. It additionally instructs about the qualities and shortcomings of every system. The investigation will help for change/revisions in existing structures by decreasing irregularities and urge new techniques to encourage applications. This is a one-of-a-kind report that offers a structures-based survey, depicts research patterns, and aids about develops a system by uncovering irregularities at each stage. It helps decrease irregularities and provides direction regarding changes in SSCM structure thinking about up and coming difficulties.
\end{abstract}

\section{Introduction}

Ones the manners which an organization does this is by taking a gander at their whole assembling procedure (here the assembling method alludes anything from an item to an administration), from where the crude materials are gotten, through the entire process inside the plant, to the utilization and eventually transfer or recyclability of their item or administration (Seitz and Wells, 2006). One may consider this is assessing the procedure from "support to support" (thinking past support to grave) or on an "actual existence cycle evaluation" type examination. By and by, organizations are taking a gander at each part of how they can select to support their business. What's more, that incorporates things one probably won't consider while considering supportability (Zhu et al., 2005) environmental components and social variables, and financial elements. If an organization's crude materials are removed by constrained kid work in an underdeveloped nation, and their business with that source is propping them up, at that point, they're not maintaining a viable business, regardless of where they're found or what procedure do they pursue (Zailani et al., 2009). 
There is a quickly expanding mindfulness in an industry that the present stock chains are flawed. Until this point, many assembling organizations make waste and contamination and are compromising the presence of life on earth. Subsequently, these difficulties and weights push firms to think about the ecological effect while doing their business truly. As the number of inhabitants on the planet increments and asset accessibility diminishes, organizations are beginning to understand that supply chains must be re-structured (Carter and Jennings, 2002). From the organization's point of view, they should depict the ecologically nice picture of items, procedures, frameworks, and advances, and how business is led (Vachon and Klassen, 2006a). Ongoing advancements on the planet's financial atmosphere make vulnerability in the business condition, which makes the need for associations to take a gander at reproducing and rebuilding to improve their system to continue the business and profitability while staying focused in the commercial center.

Furthermore, associations are confronting expanding worldwide network requests through media and non-legislative associations (NGOs) relating to the supportability part of their advancement (Sarkis, 2001). As indicated by Porter and Kramer (2006), organizations are progressively expected to expand their manageability endeavors past their tasks to incorporate their providers and live up to their client's supportability desires. Ground-breaking organizations are, as of now, finding a way to create manageability inside their stockpile chains.

As indicated by Carter and Jennings (2002), the stock chains should be shut circled, ecologically benevolent, and save and use a couple of assets as would be prudent. In this manner, numerous analysts asserted that the executives' eventual fate is supportability (Carter and Jennings, 2002, 2004; Murphy and Poist, 2002; Penfield, 2009). McKone-Sweet (2004) asserted that organizations feel the squeeze to improve the social and ecological principles any place they can apply their influence, for example, at their providers and further along with the store network. The vast majority of these weights center on the re-appropriating exercises from huge Western firms that source contribution from minimal effort makers and specialist co-ops in creating nations by overlooking the social and natural disintegrating issues supporting the momentary profitability of the associations (Leenders et al., 2006).

Carter and Mol (2006) expressed that Asia is intensely accentuating maintainability despite the distinction between corporate social obligation and supportability among Europe and Asia. Regarding Malaysia, Zailani et al. (2009) examined the critical drivers of the board's economic inventory network. Be that as it may, Eltayeb and Zailani (2009) inquired about the degree of the appropriation of a green inventory network among ISO 14001 certified fabricating firms inside Malaysia, while the experimental paper is keen on deciding the degree of the association of Malaysian organizations in the supportable production network. It also focused on a verifiable inventory network inside an association and their association with a feasible store network presentation.

\section{Review of Literature for Sustainable Supply Chain Management framework.}

Because of the TBL ideas of financial, ecological, and social parts of business obligation and an audit of SCM writing, Carter and Rogers (2008) characterized SSCM as "the key, straightforward mix and accomplishment of an association's social, natural, and monetary objectives in the deliberate coordination of key between hierarchical business forms for improving the long haul monetary execution of the individual organization and its inventory chains" and conceptualized their model as appeared in Figure 1. The largest financial execution happens at the convergence of natural, social, and monetary performance, as shown in the figure above. Carter and Rogers (2008) were of the feeling that the organizations need to at the same time augment the execution of every one of the three 
elements of the triple main concern to beat associations that endeavor to amplify financial performance Carter and Rogers (2008).

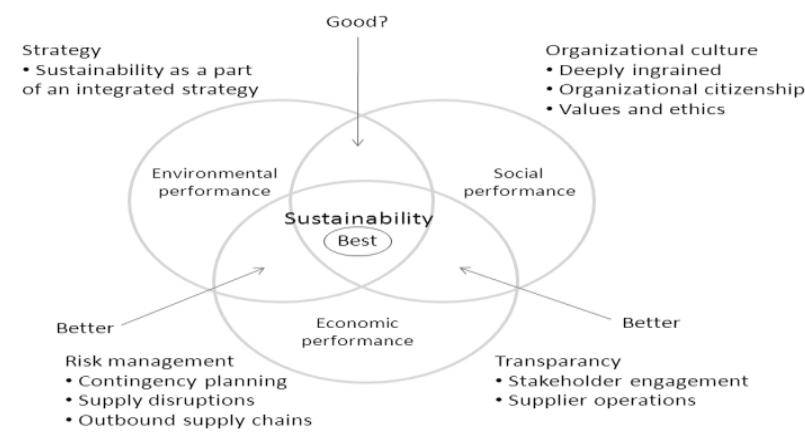

Figure 1 Sustainable Supply Chain Management (Source: Carter and Rogers, 2008)

Pagell and $\mathrm{Wu}(2009)$ characterized a supportable store network as "one that performs well on both customary proportions of benefit and misfortune just as on the extended conceptualization of They inspected the chain in its all together, by expressly analyzing both the social and natural results of the inventory network exercises. The case examination recognizes that the hierarchical ability to improve and positive administration direction towards maintainability is an antecedent to the economic production network of the board. It additionally lineate the activities performed by supervisors of feasible stock chains, viz. they work together with non-customary individuals, for example, NGOs, controllers, contenders, and individuals from the network; and they center around sourcing side exercises, for example, provider affirmation, including social and condition criteria in provider choice. Along these lines, the association's advancement capacities and its arrangement towards natural, social, and monetary objectives lead to a monetarily suitable just as supportable inventory network (Figure 2).

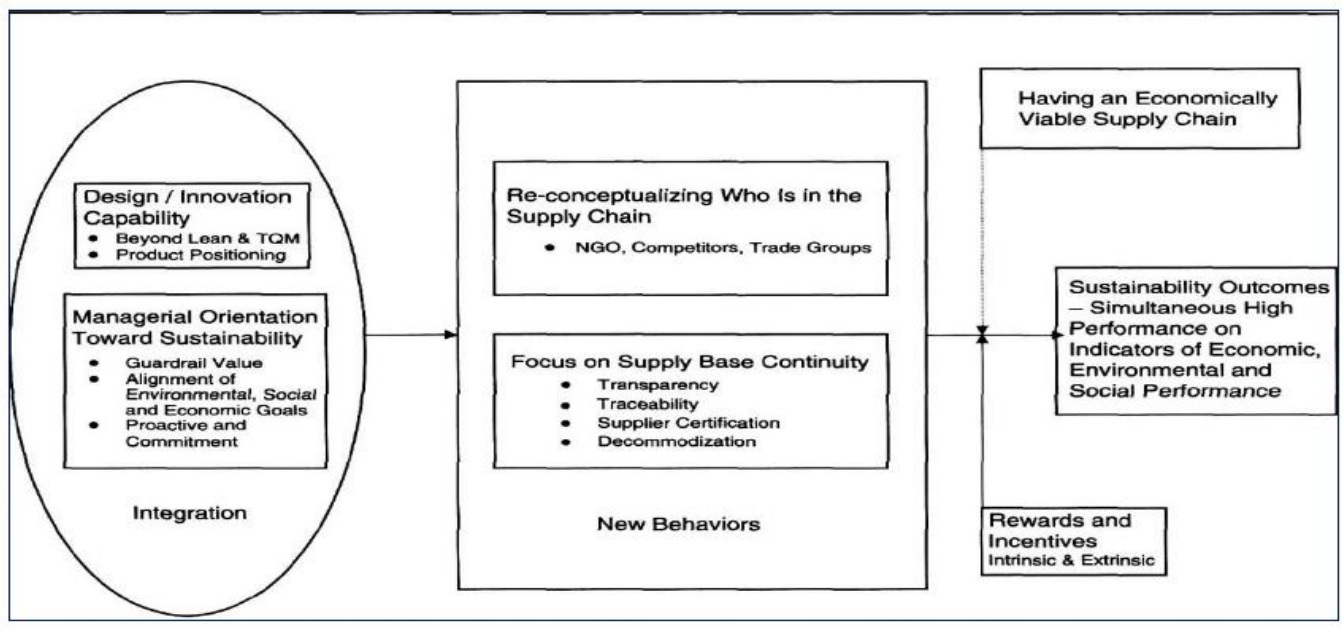

Figure 1 A Model for SSCM Practices (Source: Pagell and Wu, 2009)

Mann et al. (2010) used the 'balanced scorecard' method to classify the drivers that motivate firms towards creating sustainable supply chains.

Seuring and Müller (2008) characterize SSCM as "the administration of material, data, and capital streams just as a collaboration among organizations along with the store network while taking objectives from every one of the three elements of practical advancement, i.e., financial, ecological 
and social, into the record which are gotten from client and partner requirements."Seuring and Müller (2008), individuals in a feasible inventory network need to satisfy natural and social criteria in that capacity yet similarly need to stay focused by gathering client requests and related monetary standards.

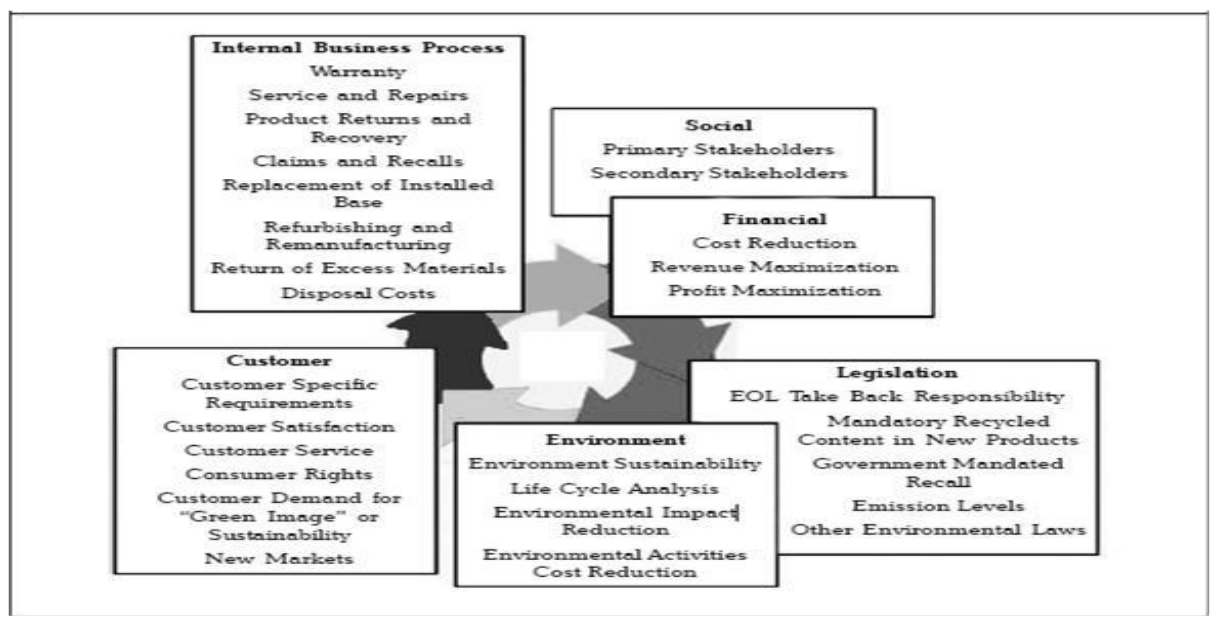

Figure 3 Sustainable Supply Chain drivers (Source: Mann, et al., 2010)

Ramudhin et al. (2010) embraced this definition and proposed their system (Figure 4) that fuses every three elements of maintainability: financial, social, and ecological. Here store network financial aspects are thought about by limiting the all-out strategic expense or amplifying the benefit over the various inventory network exercises (buying, generation, warehousing, conveyance, reusing, and so on). Ecological manageability targets diminishing greenhouse gases (GHGs) discharges while the social measurement prescribes lessening pressure and improving the personal satisfaction of society.

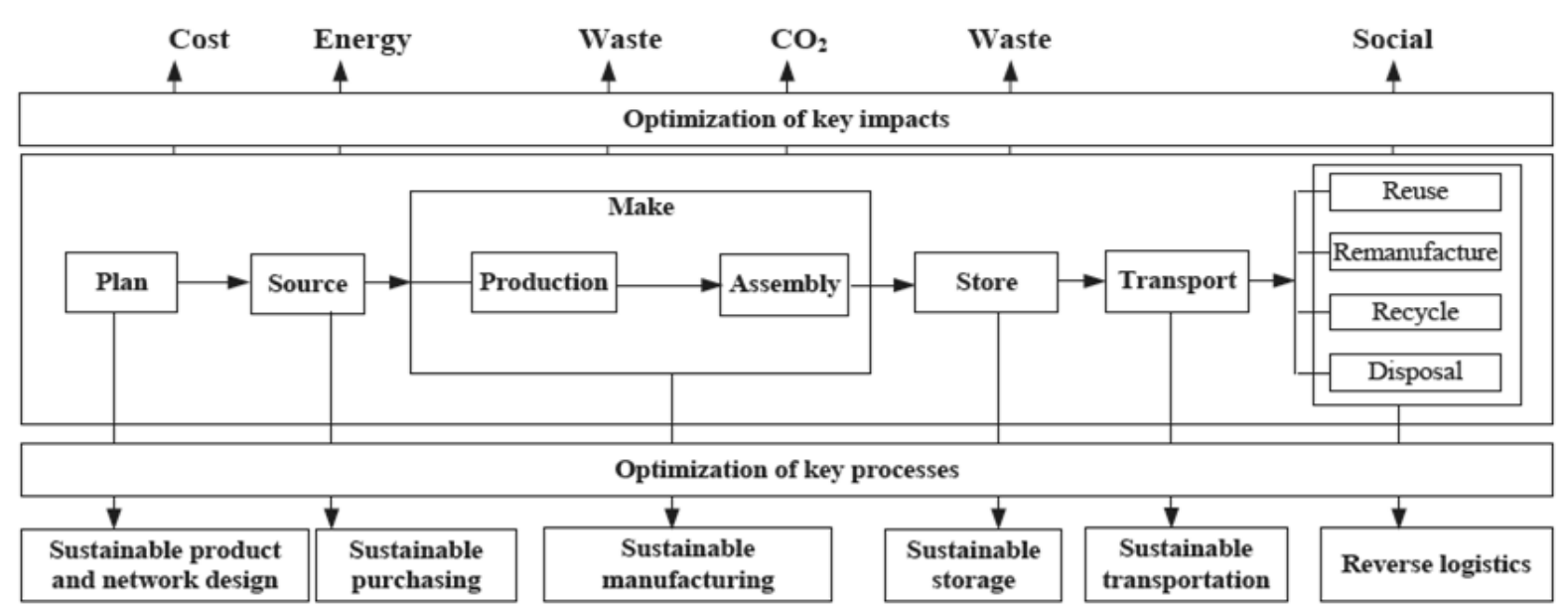

Figure 2 Sustainable Supply Chain Management (Source: Ramudhin et al., 2010)

Dey et al. (2011) coordinated maintainability with the various procedures in an inventory network. Figure 5 demonstrates an improved inventory network separated into the production network, esteem including chain, appropriation chain, and the invert coordination's chain. The system likewise incorporates the rising thought of turnaround coordination, which appeared as the practical part of Dey et al.'s arrangement (2011). 


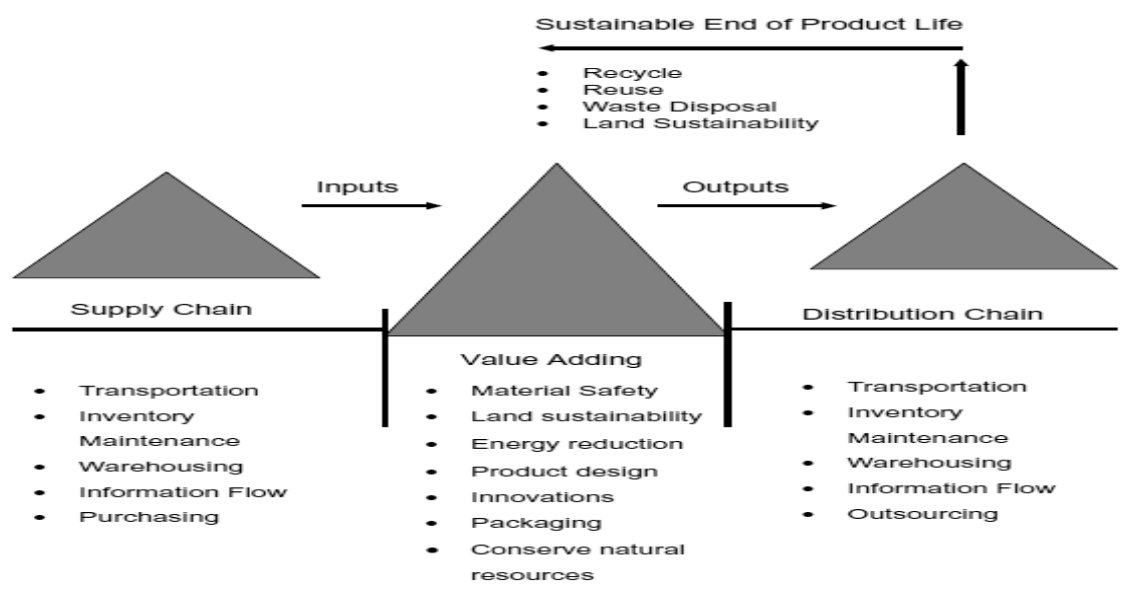

Figure 5 SSCM Frameworks (Source: Dey et al., 2010)

Hassini et al. (2012) visualize a reasonable inventory network as wheels establishing six spokes (Figure 6) speaking to the significant capacities inside the chain: sourcing, change, conveyance, incentive, clients, and reusing Hassini et al. (2012). Aside from imagining the feasible store network wheel, they recognized nine factors in a reasonable inventory network: market powers, approach and guidelines, science and innovation, item improvement, processability, sourcing and tasks, transport and coordination, promoting and advertising, and social issues. They additionally talked about that how these variables add to make the inventory network economical.

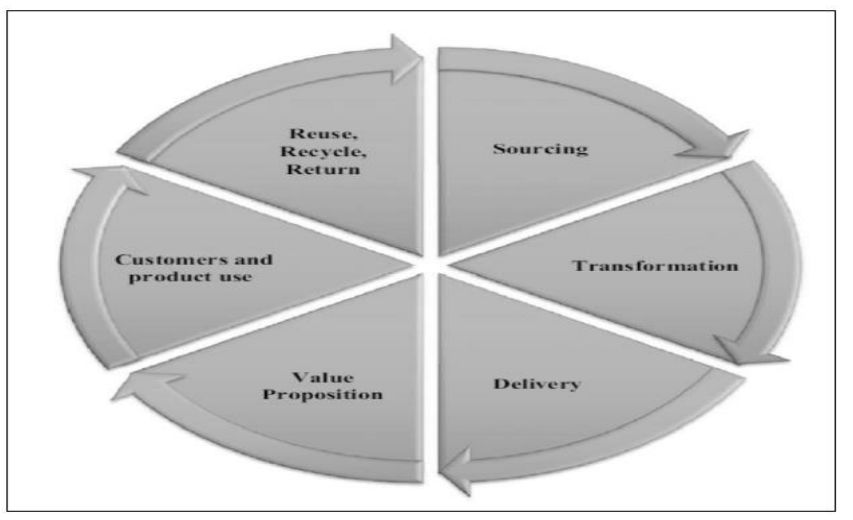

Figure 6 SSCM Framework (Source: Hassini et al., 2012)

The most worthy meaning of maintainability in writing recommends satisfying three critical measurements, viz. financial, ecological, and social. In any case, the creators believe that the correct use of the board (all levels) on store network entertainers, for example, XY measurement of the system, tends to the monetary duty of the SSCM. Anyway, the becoming ecological and social worry to the inventory network the board is included as third (Z) measurement "Supportability" to propose this three (XYZ)- dimensional system of SSCM. Sink and Tuttle (1989) guarantee that "you can't oversee what you can't measure".For any business association, estimation of its presentation is essential. Estimate of store network procedures is fundamental for improving the productivity and viability of inventory network the executives. The exhibition metric should be incorporated and lined up with the association's business objectives. This measurement has suggestions for all board degrees (for example, key, strategic, and operational) and has unmistakable and elusive qualities. 


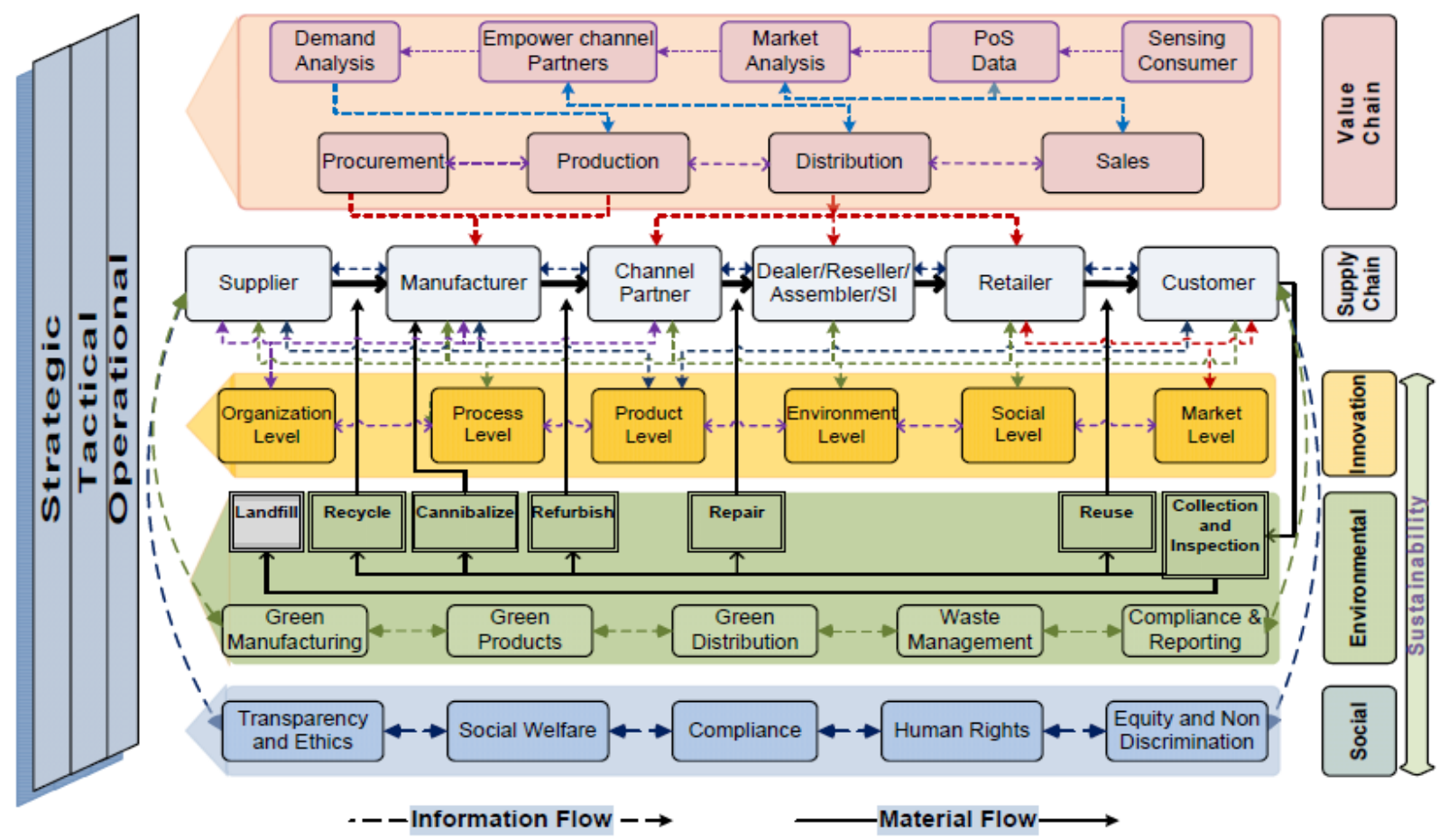

Figure 7 3-D SSCM Framework (Source: Gupta et al., 2015)

Sustainability has been defined in the literature regarding three key dimensions: economic, environmental, and social. According to J. Elkington (1998), the highest degree of financial performance will occur where ecological, social, and economic arrangements connect. Carter and Rogers are a husband and wife team (2008). Few studies have demonstrated that an organization's innovative capabilities and alignment with environmental, social, and economic goals lead to a supply chain that is both commercially viable and sustainable. While few have recommended internal business processes, customer, reverse logistics processes, waste management, energy conservation, government regulation, M. Pagell and Z. Wu (2009), M. Pagell and Z. Wu (2009), M. Pagell and Z. Wu (2009), M. Pagell and Z. Wu (2009), M. Pagell and Z. Wu (2009), fair trade practices, societal wellbeing, etc.

\begin{tabular}{|l|l|l|l|l|}
\hline S.No & Year & Author & Contribution & \multicolumn{1}{|c|}{$\begin{array}{c}\text { Sustainability } \\
\text { Parameters }\end{array}$} \\
\hline 1 & 1999 & Elkington & $\begin{array}{l}\text { Economic, environmental, and social } \\
\text { sustainability are all part of the Triple } \\
\text { Bottom Line concept. }\end{array}$ & $\begin{array}{l}\text { Economic, environmental, } \\
\text { and social factors all come } \\
\text { into play. }\end{array}$ \\
\hline 2 & 2008 & $\begin{array}{l}\text { Carter and } \\
\text { Rogers }\end{array}$ & $\begin{array}{l}\text { Best monetary execution will happen } \\
\text { at the crossing point of ecological, } \\
\text { social, and financial execution }\end{array}$ & $\begin{array}{l}\text { Economic, Environment } \\
\text { and Social }\end{array}$ \\
\hline 3 & 2009 & $\begin{array}{l}\text { Pagell and } \\
\text { Wu }\end{array}$ & $\begin{array}{l}\text { Association's development abilities } \\
\text { and its arrangement towards natural, } \\
\text { social, and financial objectives lead to } \\
\text { the supportable production network }\end{array}$ & $\begin{array}{l}\text { Economic, environmental, } \\
\text { and social innovation have } \\
\text { all been brought to the mix. }\end{array}$ \\
\hline 4 & 2010 & $\begin{array}{l}\text { Mann et } \\
\text { al. }\end{array}$ & $\begin{array}{l}\text { monetary, internal business process, } \\
\text { client, condition, enactment, and } \\
\text { social are distinct drivers for cost- } \\
\text { effective SCM techniques based on } \\
\text { the 'adjusted scorecard design.' }\end{array}$ & $\begin{array}{l}\text { Financial, } \\
\text { environmental, internal } \\
\text { procedures, customer, and } \\
\text { legislative issues are } \\
\text { considered. and }\end{array}$ \\
\hline
\end{tabular}




\begin{tabular}{|l|l|l|l|l|}
\hline 5 & 2010 & $\begin{array}{l}\text { Ramudhin } \\
\text { et al. }\end{array}$ & $\begin{array}{l}\text { Structure fusing each of the three } \\
\text { measurements of manageability, } \\
\text { included greenhouse gases (GHGs) } \\
\text { discharges, vitality preservation, } \\
\text { clamor, traffic clog, and worry as } \\
\text { variables }\end{array}$ & $\begin{array}{l}\text { Environment - Reverse } \\
\text { Logistics, Energy } \\
\text { conservation; Societal } \\
\text { wellbeing }\end{array}$ \\
\hline 6 & 2011 & Dey et al. & $\begin{array}{l}\text { Incorporated manageability with the } \\
\text { various procedures in an inventory } \\
\text { network supportable part of the } \\
\text { bargain. }\end{array}$ & $\begin{array}{l}\text { Product 'End of Life' } \\
\text { management, Value Chain, } \\
\text { Distribution Chain }\end{array}$ \\
\hline 7 & 2012 & $\begin{array}{l}\text { Hassini et } \\
\text { al. }\end{array}$ & $\begin{array}{l}\text { Included approaches, guidelines, } \\
\text { morals, reasonable exchange rehearses } \\
\text { as the measurement is social } \\
\text { maintainability. }\end{array}$ & $\begin{array}{l}\text { RoHS, recycling, regulations, } \\
\text { and fair trade practices are all } \\
\text { terms that come to mind } \\
\text { when thinking of green } \\
\text { design. }\end{array}$ \\
\hline 8 & 2013 & $\begin{array}{l}\text { Gupta et } \\
\text { al. }\end{array}$ & $\begin{array}{l}\text { It proposed a three-dimensional view } \\
\text { of SSCM, with economics as a } \\
\text { separate metric, development } \\
\text { alongside condition, and social as a } \\
\text { determinant of maintainability. }\end{array}$ & $\begin{array}{l}\text { Economic, environmental, } \\
\text { and social factors, as well as } \\
\text { innovation and management, } \\
\text { are all elements. }\end{array}$ \\
\hline
\end{tabular}

Table 1 Integrative Review of SSCM Frameworks

Supportability can be accomplished by stockpile chains that are inventive, condition conscious, and have social targets as one premise of working together. The integrative writing audit of the SSCM systems featuring the supportability parameters by each writer is condensed in Table 1 . This exploration has analyzed the association's financial duty and its connection with advancement, condition wellbeing, and social welfare. Because of ends drawn from the contextual investigations and coordinated audit of existing SSCM structures, another modern system pertinent explicitly to the material industry is created.

\section{Theoretical Framework}

To all the more likely comprehend the impact of SSCM practices and particularity put together assembling practices concerning Sustainable inventory network responsiveness, and production network responsiveness on the upper hand, a system is set up which portrays the causal connections between SSCM rehearses, seclusion based assembling rehearses, store network responsiveness, and upper hand (Figure 8). The basic fundamental of this examination structure is as follows: The SSCM rehearses (between associations) of a firm will affect the inventory network responsiveness; likewise, the measured quality-based assembling rehearses inside an association will affect the production network responsiveness. Finally, Sustainable store network responsiveness will affect the upper hand of a firm. Figure 8 shows the hypothetical model delineating the four developments talked about in this section. The numbers by every bolt relate to the Sevan theories to be created in this report.

K.V.Sambasiva Rao et al. (1994) gave a strategies system to rehearsing the FMS in India. Carl Gustav Johannsen et al. (1996) built up another vital quality administration (SQM) system. The producer needs to give some unmistakable instruments that would deal with data progression. Data, the board for assembling, is being encouraged in a KBS (Knowledge-Based System) called AM-CHECK is being created through a joint research exertion between Iowa state college and the University of Northern Iowa (H. Fred Walker et al., 1994). Dr. Zhibin Jiang et al. (2003) proposed a pre-essential for Sustainable assembling framework in the setting. 


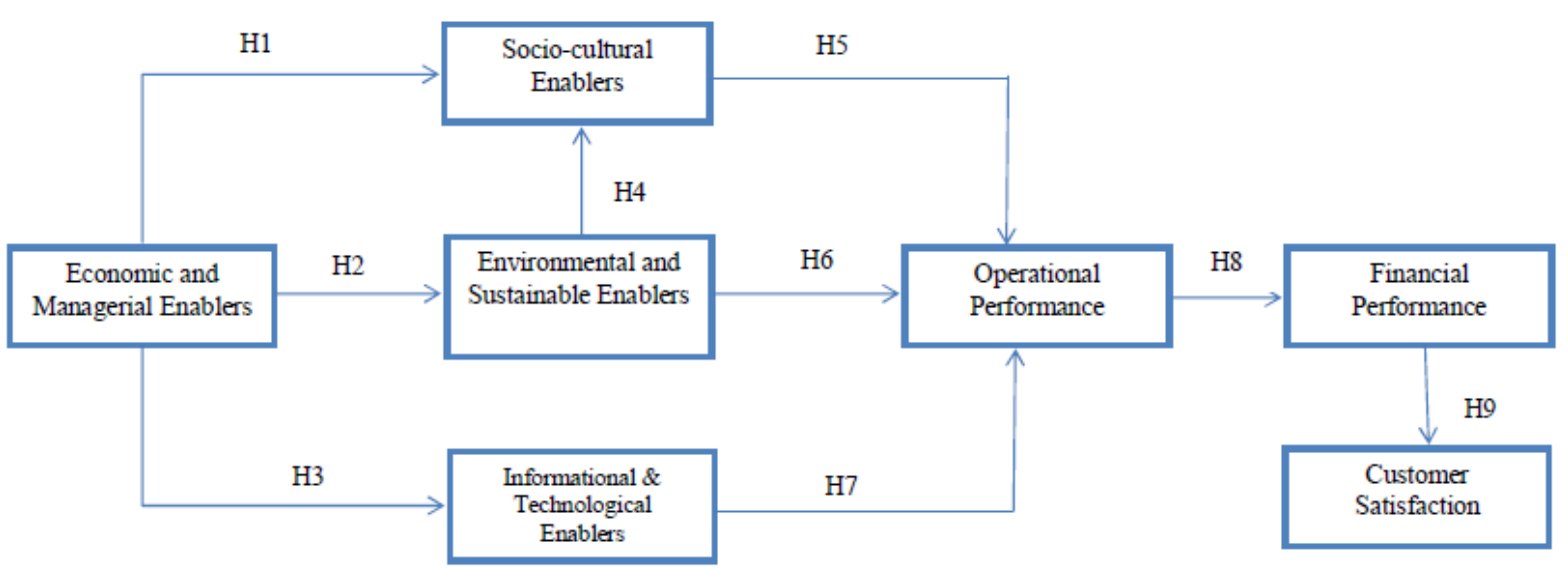

Figure 8 Final Frameworks for SSCM in Textile Organization.

\section{In conclusion, the establishment of inconsistencies at three stages covering frameworks}

\section{Research trends and constructs:}

Following research objectives and related consistent prerequisites about a system, examine patterns; following an organized procedure, creators led this examination. No audit study has ever announced irregularities of existing SSCM systems and direction about new prerequisites of industry. In SSCM research and application space, a few specialists and professionals have proposed their structures, and a few survey concentrates are additionally accessible. Be that as it may, none of the investigations controls structure squares and offers a general picture of shaping the system from essentials after understanding the qualities and shortcomings in the current designs and research patterns. Creators accept that this examination won't just encourage new research and applications in the SSCM space; however, different regions will likewise be impacted. Firmly suggest for this kind of study, and express that change and a general comprehension about irregularities in existing structures will lead towards the structure of better and segment explicit systems.

As characterized at the start of the examination, the primary target of this investigation was to investigate the irregularities in the current SSCM systems, which were distinguished in three phases. Creators build up an irregularity in systems and in their development at three unique stages.

- The principal organizes irregularity is reflected at a system level. Numerous specialists overlook the vital green angles. This irregularity energizes perplexity with respect to the application that whether one ought to pursue a conventional system or after important alterations, application, and area-based structure ought to be utilized.

- In the subsequent stage, irregularities are reflected at structure square or develop level. Creators endeavor to investigate irregularity at structure square or develop level. For this, first, the builds of the current systems are organized. From this examination, one gets genuinely smart thoughts about the current irregularity winning at the developing level. Creators demonstrate about the irregularities as well as guide in regards to the new prerequisites of industry and, as needs be recommend, four new arrangements of builds and sub-develops. Creators accept this expansion will be valuable for the two analysts and professionals. 
This examination study likewise contributes to the refinement of SSCM builds detailed by a few creators in their systems. This examination likewise orders the checked on develops for understanding exploration patterns of SSCM structures in a superior manner.

\section{Implications for researchers and practitioners}

For a half and half arrangement like SSCM, both structure and its development are significant. All things considered, one requires both 'outline' and the 'parts inside the casing' at that point; just one can do equity with the ideal generally speaking result anticipated from a mixture arrangement like SSCM. Accordingly in building up an appropriate structure requires commitments from the two networks with a reasonable comprehension of the system and its structure squares. The scientist helps in building up the hypothetical establishments, and methodological parts of a structure through expert contributes towards its execution and viable appropriateness. The two of them supplement and supplement to one another.

As regularly, the need emerges to check whether the system is working appropriately or requires alteration. This modification winds up simpler if a general picture is accessible. So also, a legitimate structure in the wake of joining essential changes enables experts to execute the whole procedure easily. In this way, for a cross-breed arrangement like SSCM, an appropriate system is fundamental, which could cover all viewpoints and encourage smooth application. The examination reports following commitments and suggestions.

1) The present investigation offers a solitary stage and endeavors to meet the prerequisites of the two analysts and professionals. It distinguishes and depicts the articles portraying the SSCM usage structure among a few areas in a single report. The experts will think that it's valuable and get the structure of their advantage, while the academicians can expand inquire about zones, which are yet to be investigated utilizing the system. Creators expect that making an uber picture will be valuable both in growing new systems by lessening irregularities in the current structure and in encouraging the SSCM applications.

2) The examination may demonstrate to be valuable in diminishing and in preplanning the vital costs for a mixture drive like SSCM. As per Timans et al. (2014), "the completeness of any system is critical in light of the fact that the usage cost of any quality improvement technique at association causes extremely high ventures." Thus, guaranteeing the relevance of structure before its usage is incredibly noteworthy. This examination investigates the qualities and shortcomings of the accessible SSCM structures and furthermore determines the change expected to improve the immaterialness' of the accessible SSCM systems. Consequently, the specialists can limit the danger of usage disappointment and expand the additions to concentrate out of execution. Creators expect that it will help in decreasing the execution costs also.

3) As indicated by Vinodh et al. (2011), scientists and professionals are commonly confounded and dis-fulfilled while applying the current SSCM systems, and they are likewise not ready to evaluate the viability of these structures. The characterizations embraced for evaluating the current SSCM structures feature the uniqueness of this examination, as it depicts the current situation with SSCM systems over a few measurements and furthermore helps in responding to the exploration addresses brought up at the start of this investigation. From every order, the analysts can pick the insufficiencies and deficiencies of the current SSCM structures and work on the confinements to broaden the SSCM look into in the system heading.

4) It is fascinating to take note that exceptionally restricted SSCM systems incorporated the part of green and manageability inside their structures. Be that as it may, the present situation is moving towards cleaner creation, and any system disregarding these angles is viewed as fragmented and non-adequate by the experts. The specialists can adjust the above-said 
perspectives for structure new SSCM systems, which can upgrade their snappy adoptability among businesses. So also, creators accept that their endeavor to incorporate most recent patterns like the web of things (IoT), information investigation is additionally novel and energizes new research and applications in the space region of SSCM.

5) This examination proposes the essential arrangement of fixings (builds) of the SSCM structure, which can be additionally stretched out by analysts to build up the far-reaching SSCM system. The proposed developments are the blended mix of the builds of existing SSC structures with the extra kind of present system needs raising by a few professionals to satisfy contemporary necessities.

6) As saw in writing, the current SSCM structures neglected to put the right extent of reasonable and production network the board together for structure the SSCM system. From the experts' view, the essential thought process behind executing the SSCM system is to take out squanders at first and later control the quality administration viewpoints in an equivalent proportion. Along these lines, the analysts can move in the direction of advancement of the SSCM system that could give the best blend of supportable and inventory network to the executives.

7) From the audit, albeit one finds that the particular inclusion in regards to develops in the examinations make need to find out about these structure squares with the goal that professionals could use SSCM thinking about their area explicit necessities. Through these investigations, analysts and professionals locate that a stage is accessible, yet at the same time, the central necessities towards a far-reaching inclusion of development and sub-build exist. This need is likewise communicated by the specialists to quicken the SSCM usage to choose a plan for their SSCM application techniques. This need is likewise communicated to adjust existing structures in the wake of understanding the current builds and missing connections. Creators accept that their endeavor will address this prerequisite of the two networks.

\section{Limitations and future scope of the study}

As referenced before, creators endeavored to uncover irregularities at three phases. Despite the fact that creators are giving adequate insights regarding the qualities and shortcomings of structures, inquire about patterns and irregularities at the developing level, however, are not proposing any thorough and coordinated system, which rises as a significant constraint of the examination. A complete structure encourages usage as well as aids about generally execution estimation necessities like proficiency, use of machines (Pachpor et al., 2017), viability, process duration decrease, and efficiency. Additionally, creators attempted to streamline the importance of the system and develop yet at the same time expect that because of countless builds, analysts and experts may confront a few challenges. As creators offer point by point picture, however, don't approve about the gathering of develops. It certainly rises as a constraint of the examination.

Counting the huge number of builds inside the structure, by and large, expands the multifaceted nature of the system, so the people new to SSCM may think that it's hard to actualize. Yet, this shortcoming can be tended to by appropriate preparing and including a prepared mentor cum advisor. The present investigation gathers the accessible developments of the SSCM structure and furthermore recommends the requirement for different builds that could make the SSCM system complete; however, the examination doesn't propose any structure. It certainly shows up as a shortcoming of the study. Nonetheless, it is as of now referenced to start with that the target of the present examination is to recognize irregularities in the current SSCM systems. The analysts are urged to use the builds exhibited in the investigation and build up a far-reaching structure and approve it by executing among various mechanical divisions, which may later be useful for experts to actualize SSCM effectively. 
The creators didn't consider the hazard in considering every one of the builds together. The creators accept that their examination endeavor will be advantageous for specialists and professionals and will help in creating important structures by diminishing irregularities, and will demonstrate to be application amicable. This will quicken the use of SSCM in various parts.

\section{REFERENCES}

- Abdullah, L. and Zulkifli, N. (2015), "Integration of fuzzy AHP and interval type-2 fuzzy DEMATEL: An application to human resource management", Expert Systems with Applications, Elsevier Ltd, Vol. 42 No. 9, pp. 4397-4409.

- Antony, J. (2012), "Lean Six Sigma for higher education institutions (HEIs): Challenges, barriers, success factors, tools/techniques," International Journal of Productivity and Performance Management, Vol. 61 No. 8, pp. 940-948.

- Avikal, S., Mishra, P.K. and Jain, R. (2014), "A Fuzzy AHP and PROMETHEE methodbased heuristic for disassembly line balancing problems," International Journal of Production Research, Vol. 52 No. 5, pp. 1306-1317.

- Ayağ, Z. (2010), "A combined fuzzy AHP-simulation approach to CAD software selection," International Journal of General Systems, Vol. 39 No. 7, pp. 731-756.

- Beikkhakhian, Y., Javanmardi, M., Karbasian, M. and Khayambashi, B. (2015), "The Application of ISM Model in Evaluating Agile Suppliers Selection Criteria and Ranking Suppliers Using Fuzzy TOPSIS-AHP Methods," Expert Systems with Applications, Elsevier Ltd, Vol. 42 No. 15-16, pp. 6224-6236.

- Bhosale, V.A. and Kant, R. (2014), "Selection of best knowledge flow practicing organization using hybrid fuzzy AHP-VIKOR method," International Journal of Decision Sciences, Risk and Management, Vol. 5 No. 3, pp. 234-262.

- Chakraborty, A. and Leyer, M. (2013), "Developing a Six Sigma framework: Perspectives from financial service companies," International Journal of Quality \& Reliability Management, Vol. 30 No. 3, pp. 256-279.

- Chaplin, L. and O'Rourke, S.T.J. (2014), "Lean Six Sigma and marketing: a missed opportunity," International Journal of Productivity and Performance Management, Vol. 63 No. 5, pp. 665-674.

- Chaurasia, B., Garg, D. and Agarwal, A. (2016), "Framework to improve performance through implementing Lean Six Sigma strategies to oil-exporting countries during recession or depression," International Journal of Productivity and Performance Management, Vol. 65 No. 3, pp. 422-432.

- Chen, L.-H. and Hung, C.-C. (2010), "An integrated fuzzy approach for the selection of outsourcing manufacturing partners in pharmaceutical R\&D," International Journal of Production Research, Vol. 48 No. 24, pp. 7483-7506.

- Chiarini, A. (2012), "Risk management and cost reduction of cancer drugs using Lean Six Sigma tools," Leadership in Health Services, Vol. 25 No. 4, pp. 318-330.

- Colicchia, C., Melacini, M. and Perotti, S. (2011), "Benchmarking supply chain sustainability: insights from a field study," Benchmarking: An International Journal, Vol. 18 No. 5, pp. 705-732.

- Corbett, L.M. (2011), "Lean Six Sigma: the contribution to business excellence," International Journal of Lean Six Sigma, Vol. 2 No. 2, pp. 118-131.

- Curwen, L.G. (2012), "Challenges and solutions sustainable apparel product development: A case study of Eileen Fisher," pp. 1-82. 
- Delgado, C., Ferreira, M. and Branco, M.C. (2010), "The implementation of Lean Six Sigma in financial services organizations," Journal of Manufacturing Technology Management, Vol. 21 No. 4, pp. 512-523.

- Ding, H., Zhao, Q., An, Z., Xu, J. and Liu, Q. (2015), "Pricing strategy of environmental sustainable supply chain with internalizing externalities," International Journal of Production Economics, Elsevier, Vol. 170, pp. 563-575.

- Ding, J.-F. (2011), "Applying fuzzy AHP approach to assess key-value activities for ocean freight forwarders in Taiwan," Journal of Interdisciplinary Mathematics, Vol. 14 No. 3, pp. 331-346.

- Duarte, S. and Cruz-Machado, V. (2009), "Modelling Lean and Green: a review from Business models," International Journal of Lean Six Sigma, Vol. 4 No. 3, pp. 1-23.

- Dubey, R. and Gunasekaran, A. (2015), "Shortage of sustainable supply chain talent: an industrial training framework," Industrial and Commercial Training, Vol. 47 No. 2, pp. 8694.

- Fabbe-Costes, N., Roussat, C. and Colin, J. (2011), "Future sustainable supply chains: what should companies scan?", International Journal of Physical Distribution \& Logistics Management, Vol. 41 No. 3, pp. 228-252.

- Faisal, M.N. (2012), "Sustainability metrics for a supply chain: The case of small and medium enterprises," International Journal of Services and Operations Management, Vol. 13 No. 3, pp. 392-414.

- Fleury, A.M. and Davies, B. (2012), "Sustainable supply chains-minerals and sustainable development, going beyond the mine," Resources Policy, Elsevier, Vol. 37 No. 2, pp. 175178.

- Freeman, J. and Chen, T. (2015), "Green supplier selection using an AHP-Entropy-TOPSIS framework," Supply Chain Management: An International Journal, Vol. 20 No. 3, pp. 327340 .

- Ganguly, K.K. and Guin, K.K. (2013), "A fuzzy AHP approach for inbound supply risk assessment," Benchmarking: An International Journal, Vol. 20 No. 1, pp. 129-146.

- Garza-Reyes, J.A. (2015), "Green lean and the need for Six Sigma," International Journal of Lean Six Sigma, Vol. 6 No. 3, pp. 226-248.

- Gijo, E. V. and Antony, J. (2014), "Reducing patient waiting time in the outpatient department using lean six sigma methodology," Quality and Reliability Engineering International, Vol. 30 No. 8, pp. 1481-1491.

- Goffnett, S.P., Lepisto, L. and Hayes, R. (2006), "Using the socio-economic approach to management to augment Lean Six Sigma," International Journal of Productivity and Performance Management, Vol. 65 No. 1, pp. 80-97.

- Govindan, K., Azevedo, S.G., Carvalho, H. and Cruz-Machado, V. (2014), "Impact of supply chain management practices on sustainability," Journal of Cleaner Production, Elsevier Ltd, Vol. 85, pp. 212-225.

- Govindan, K., Khodaverdi, R., and Jafarian, A. (2013), "A fuzzy multi-criteria approach for measuring sustainability performance of a supplier based on triple bottom line approach," Journal of Cleaner Production, Elsevier Ltd, Vol. 47, pp. 345-354.

- Green, K., Morton, B., and New, S. (1998), "Green purchasing and supply policies: do they improve companies' environmental performance?", Supply Chain Management: An International Journal, Vol. 3 No. 2, pp. 89-95. 
- Habidin, N.F., Salleh, MI, Md Latip, N.A., Azman, MNA and Mohd Fuzi, N. (2016), "Lean six sigma performance improvement tool for automotive suppliers," Journal of Industrial and Production Engineering, Vol. 1015 No. February, pp. 1-21.

- Handfield, R., Walton, S. V., Sroufe, R. and Melnyk, S.A. (2002), "Applying environmental criteria to supplier assessment: A study in the application of the Analytical Hierarchy Process," European Journal of Operational Research, Vol. 141 No. 1, pp. 70-87.

- Hartini, S. and Ciptomulyono, U. (2015), "The Relationship between Lean and Sustainable Manufacturing on Performance: Literature Review," Procedia Manufacturing, Elsevier BV, Vol. 4 No. Less, pp. 38-45.

- Hassini, E., Surti, C. and Searcy, C. (2012), "A literature review and a case study of sustainable supply chains with a focus on metrics," International Journal of Production Economics, Elsevier, Vol. 140 No. 1, pp. 69-82.

- He, T., Ho, W., Man, C.L.K. and Xu, X. (2012), "A fuzzy AHP based integer linear programming model for the multi-criteria transshipment problem," The International Journal of Logistics Management, Vol. 23 No. 1, pp. 159-179.

- Heisig, P. (2009), Harmonisation of knowledge management - comparing $160 \mathrm{KM}$ frameworks around the globe, Journal of Knowledge Management, Vol. 13, doi:10.1108/13673270910971798.

- Hilton, R.J. and Sohal, A. (2012), "A conceptual model for the successful deployment of Lean Six Sigma," International Journal of Quality \& Reliability Management, Vol. 29 No. 1, pp. 54-70.

- Huang, C.-T., Yeh, T.-M., Lin, W.-T. and Lee, B.-T. (2009), "A fuzzy AHP-based performance evaluation model for implementing SPC in the Taiwanese LCD industry," International Journal of Production Research, Vol. 47 No. 18, pp. 5163-5183.

- Jin, M., Switzer, M. and Agirbas, G. (2008), "Six Sigma and Lean in healthcare logistics center design and operation: a case at North Mississippi Health Services," International Journal of Six Sigma and Competitive Advantage, Vol. 4 No. 3, p. 270.

- Jou, Y.T., Hwang, C.H. and Lin, W.T. (2010), "A performance evaluation of introducing SixSigma to aviation-related industries in Taiwan," Journal of Information and Optimization Sciences, Vol. 31 No. 3, pp. 499-511.

- Kanigolla, D., Cudney, E.A. and Corns, S.M. (2014), "Enhancing engineering education using project-based learning for Lean and Six Sigma," Vol. 5 No. 1, pp. 45-61.

- Kannegiesser, M., Günther, H.-O. and Gylfason, Ó. (2014), "Sustainable development of global supply chains-part 2: investigation of the European automotive industry", Flexible Services and Manufacturing Journal, Vol. 26 No. 1-2, pp. 48-68.

- Kannegiesser, M., Günther, HO and Autenrieb, N. (2015), "The time-to-sustainability optimization strategy for sustainable supply network design," Journal of Cleaner Production, Elsevier Ltd, Vol. 108, pp. 451-463.

- Kara, S. and Ibbotson, S. (2011), "Embodied energy of manufacturing supply chains," CIRP Journal of Manufacturing Science and Technology, CIRP, Vol. 4 No. 3, pp. 317-323.

- Kara, S., Ibbotson, S. and Kayis, B. (2014), "Sustainable product development in practice: an international survey," Journal of Manufacturing Technology Management, Vol. 25 No. 6, pp. 848-872.

- Kim, K., Jeong, B. and Jung, H. (2014), "Supply chain surplus: Comparing conventional and sustainable supply chains," Flexible Services and Manufacturing Journal, Vol. 26 No. 1-2, pp. 5-23. 
- Koning, H. De, Does, R.J.M.M. and Bisgaard, S. (2008), "Lean Six Sigma in financial services", Int. J. Six Sigma and Competitive Advantage, Vol. 4 No. 1, pp. 1-17.

- Kumar, A., Shankar, R. and Debnath, RM (2015), "Analyzing customer preference and measuring relative efficiency in telecom sector: A hybrid fuzzy AHP/DEA study," Telematics and Informatics, Elsevier Ltd, Vol. 32 No. 3, pp. 447-462.

- Kumar, D. and Rahman, Z. (2015), Sustainability adoption through buyer-supplier relationship across the supply chain: A literature review and conceptual framework, International Strategic Management Review, Holy Spirit University of Kaslik, Vol. 3, doi:10.1016/j.ism.2015.04.002.

- Kumar, M., Antony, J. and Cho, B.R. (2009), "Project selection and its impact on the successful deployment of Six Sigma," Business Process Management Journal, Vol. 15 No. 5, pp. 669-686.

- Kumar, V., Koehl, L. and Zeng, X. (2016), "A full yarn integrated tag for tracking the international textile supply chain," Journal of Manufacturing Systems, The Society of Manufacturing Engineers, Vol. 40, pp. 76-86.

- Kuo, R.J., Lee, L.Y. and Hu, T.-L. (2010), "Developing a supplier selection system through integrating fuzzy AHP and fuzzy DEA: a case study on an auto lighting system company in Taiwan," Production Planning \& Control, Vol. 21 No. 5, pp. 468-484.

- Laureani, A., Antony, J. and Douglas, A. (2010), "Lean six sigma in a call center: a case study," International Journal of Productivity and Performance Management, Vol. 59 No. 8, pp. 757-768.

- Lee, A.H.I. (2009), "A fuzzy AHP evaluation model for buyer-supplier relationships with the consideration of benefits, opportunities, costs and risks," International Journal of Production Research, Vol. 47 No. 15, pp. 4255-4280.

- Lee, K.H. and Wu, Y. (2014), "Integrating sustainability performance measurement into logistics and supply networks: A multi-methodological approach," British Accounting Review, Elsevier Ltd, Vol. 46 No. 4, pp. 361-378.

- Lertwattanapongchai, S. and William Swierczek, F. (2014), "Assessing the change process of Lean Six Sigma: a case analysis," International Journal of Lean Six Sigma, Vol. 5 No. 4, pp. 423-443.

- Li, C. (2013), "An integrated approach to evaluating the production system in closed-loop supply chains," International Journal of Production Research, Vol. 51 No. 13, pp. 4045-4069.

- Lin, C. (2013), "Application of fuzzy Delphi method (FDM) and fuzzy analytic hierarchy process (FAHP) to criteria weights for fashion design scheme evaluation," International Journal of Clothing Science and Technology, Vol. 25 No. 3, pp. 171-183.

- Lin, Y.-H. and Tseng, M.-L. (2016), "Assessing the competitive priorities within sustainable supply chain management under uncertainty," Journal of Cleaner Production, Elsevier Ltd, Vol. 112, pp. 2133-2144.

- Lintukangas, K., Hallikas, J. and Kähkönen, A.-K. (2015), "The Role of Green Supply Management in the Development of Sustainable Supply Chain," Corporate Social Responsibility and Environmental Management, Vol. 22 No. 6, pp. 321-333.

- Mallidis, I., Dekker, R. and Vlachos, D. (2012), "The impact of greening on supply chain design and cost: A case for a developing region," Journal of Transport Geography, Elsevier Ltd, Vol. 22, pp. 118-128.

- Mangla, S.K., Kumar, P. and Barua, MK (2014), "Flexible decision approach for analyzing the performance of sustainable supply chains under risks/uncertainty," Global Journal of Flexible Systems Management, Vol. 15 No. 2, pp. 113-130. 
- Manville, G., Greatbanks, R., Krishnasamy, R. and Parker, D.W. (2012), "Critical success factors for Lean Six Sigma programs: a view from middle management," International Journal of Quality \& Reliability Management, Vol. 29 No. 1, pp. 7-20.

- Martinez, D. and Gitlow, H.S. (2011), "Optimizing employee time in a purchasing department: a Six sigma case study," International Journal of Lean Six Sigma, Vol. 2 No. 2, pp. $180-190$.

- Näslund, D. (2013), "Lean and six sigma - critical success factors revisited," International Journal of Quality and Service Sciences, Vol. 5 No. 1, pp. 86-100.

- Ng, C.Y., Chuah, K.B., Yu, C. and Bieng, K. (2012), "Evaluation of Eco design alternatives by integrating AHP and TOPSIS methodology under a fuzzy environment," International Journal of Management Science and Engineering Management, Vol. 7 No. 1, pp. 43-52.

- Nicoletti, B. and Vergata, T. (2013), "Lean Six Sigma and digitize procurement," International Journal of Lean Six Sigma, Vol. 4 No. 2, pp. 184-203.

- Patil, S.K. and Kant, R. (2014a), "Ranking the barriers of knowledge management adoption in a supply chain using fuzzy AHP method," International Journal of Business Innovation and Research, Vol. 8 No. 1, pp. 52-75.

- Patil, S.K. and Kant, R. (2014b), "A fuzzy AHP-TOPSIS framework for ranking the solutions of Knowledge Management adoption in Supply Chain to overcome its barriers," Expert Systems with Applications, Elsevier Ltd, Vol. 41 No. 2, pp. 679-693.

- Prasanna, M. and Vinodh, S. (2013), "Lean Six Sigma in SMEs: an exploration through literature review," Journal of Engineering, Design and Technology, Vol. 11 No. 3, pp. 224250.

- Psychogios, A.G. and Tsironis, LK (2012), "Towards an integrated framework for Lean Six Sigma application: Lessons from the airline industry," Total Quality Management \& Business Excellence, Vol. 23 No. 3-4, pp. 397-415.

- Rathi, R., Khanduja, D. and Sharma, S.K. (2016), "A fuzzy-MADM based approach for prioritizing Six Sigma projects in the Indian auto sector," International Journal of Management Science and Engineering Management, Vol. 9653 No. May, pp. 1-8.

- Samvedi, A., Jain, V. and Chan, F.T.S. (2013), "Quantifying risks in a supply chain through integration of fuzzy AHP and fuzzy TOPSIS," International Journal of Production Research, Vol. 51 No. 8, pp. 2433-2442.

- Sarkar, S.A., Mukhopadhyay, A.R. and Ghosh, S.K. (2013), "Improvement of claim processing cycle time through Lean Six Sigma methodology," International Journal of Lean Six Sigma, Vol. 4 No. 2, pp. 171-183.

- Shukla, R.K., Garg, D. and Agarwal, A. (2014), "An integrated approach of Fuzzy AHP and Fuzzy TOPSIS in modeling supply chain coordination," Production \& Manufacturing Research, Vol. 2 No. 1, pp. 415-437.

- Singh, H., and Kumar, R. (2013), "Hybrid methodology for measuring the utilization of advanced manufacturing technologies using AHP and TOPSIS," Benchmarking: An International Journal, Vol. 20 No. 2, pp. 169-185.

- Soni, G. and Kodali, R. (2013), A critical review of supply chain management frameworks: proposed framework, Benchmarking: An International Journal, Vol. 20, doi:10.1108/14635771311307713.

- Thomas, A., Barton, R., and Chuke-Okafor, C. (2009), "Applying lean six sigma in a small engineering company - a model for change," Journal of Manufacturing Technology Management, Vol. 20 No. 1, pp. 113-129. 
- $\quad$ Timans, W., Ahaus, K., van Solingen, R., Kumar, M. and Antony, J. (2014), "Implementation of continuous improvement based on Lean Six Sigma in small- and medium-sized enterprises," Total Quality Management \& Business Excellence, Vol. 3363 No. January 2016, pp. 1-16.

- Torfi, F., Farahani, RZ and Rezapour, S. (2010), "Fuzzy AHP to determine the relative weights of evaluation criteria and Fuzzy TOPSIS to rank the alternatives," Applied Soft Computing Journal, Vol. 10 No. 2, pp. 520-528.

- Vinodh, S., Shivraman, K.R. and Viswesh, S. (2012), "AHP-based lean concept selection in a manufacturing organization," Journal of Manufacturing Technology Management, Vol. 23 No. 1, pp. 124-136.

- Yi, T.P. (2012), "Reducing electronic component losses in lean electronics assembly with Six Sigma approach," International Journal of Lean Six Sigma, Vol. 3 No. 3, pp. 206-230.

- Zaim, S., Turkyilmaz, A., Acar, M.F., Al-Turki, U. and Demirel, O.F. (2012), "Maintenance strategy selection using AHP and ANP algorithms: a case study," Journal of Quality in Maintenance Engineering, Vol. 18 No. 1, pp. 16-29. 